\title{
Nitrogen and Phosphorous Removal by Ornamental and Wetland Plants in a Greenhouse Recirculation Research System
}

\author{
Yan Chen ${ }^{1}$, Regina P. Bracy, and Allen D. Owings \\ Louisiana State University AgCenter, Hammond Research Station, 21549 \\ Old Covington Highway, Hammond, LA 70403
}

\section{Donald J. Merhaut \\ University of California, Riverside, Department of Botany and Plant Sciences, Riverside, CA 92521}

Additional index words. stormwater, water quality, biofiltration, nitrate

\begin{abstract}
A nutrient recirculation system (NRS) was used to assess the ability of four ornamental and three wetland plant species to remove nitrogen $(N)$ and phosphorous $(P)$ from stormwater runoff. The NRS was filled with a nutrient solution with total $N$ and $P$ concentrations of 11.3 and $3.1 \mathrm{mg} \cdot \mathrm{L}^{-1}$, respectively, to simulate high levels of nutrient contaminations in stormwater. Nutrient removal abilities of herbaceous perennial ornamental plants, canna (Canna $\times$ generalis Bailey) 'Australia', iris (Iris pseudacorus L.) 'Golden Fleece', calla lily [Zantedeschia aethiopica (L.) Spreng], and dwarf papyrus (Cyperus haspan L.) were compared with those of wetland plants arrow arum [Peltandra virginica (L.) Schott], pickerelweed (Pontederia cordata L.), and bulltongue arrowhead (Sagittaria lancifolia L.) in three experiments. 'Australia' canna had the greatest water consumption, total biomass production, and aboveground $N$ and $P$ content followed by pickerelweed. 'Golden Fleece' iris had higher tissue $\mathbf{N}$ concentrations than canna but much lower biomass production. Dwarf papyrus had similar total biomass as pickerelweed but less shoot biomass. $N$ and $P$ removed from the NRS units planted with canna $\mathbf{( 9 8 . 7 \%} \mathrm{N}$ and $\mathbf{9 1 . 8 \%} \mathrm{P})$ were higher than those planted with iris and arrow arum $(31.6 \%$ and $31.5 \% \mathrm{~N}$, and $38.5 \%$ and $26.3 \% \mathrm{P}$, respectively). NRS units planted with dwarf papyrus had similar nutrient recovery rate as pickerelweed, but much less total $N$ and $P$ were removed as a result of less water consumption. The NRS units planted with calla lily had lower nutrient removal than canna and pickerelweed. Our results suggest that canna is a promising ornamental species for stormwater mitigation, and harvesting the aboveground biomass of canna can effectively remove $N$ and $P$ from the treatment system. However, more research needs to be done to evaluate factors that might affect plant performance in a floating biofiltration system.
\end{abstract}

Rapid population growth and urbanization have raised concerns over stormwater runoff contamination (Bolund and Hunhammer, 1999; Walsh, 2000). Studies on watersheds indicate that excess nutrients, specifically nitrate-nitrogen $\left(\mathrm{NO}_{3}-\mathrm{N}\right)$ and soluble reactive phosphorus (i.e., $\mathrm{PO}_{4}{ }^{3-}$ ), are found in stormwater runoff exported from newly developed urban areas (Dougherty et al., 2006; Steuer et al., 1997). These pollutants degrade water quality and contribute to

Received for publication 29 Apr. 2009. Accepted for publication 9 July 2009.

This research was funded by the Lake Pontchartrain Foundation and the Louisiana Agricultural Experiment Station. Plant material supplied by AG3, Inc.

Trade names mentioned in this manuscript does not imply product endorsement by the authors and their associated institution.

We thank Roger Rosendale and Joey Quebedeaux for their technical assistance.

${ }^{1}$ To whom reprint requests should be addressed; e-mail yachen@agcenter.1su.edu. is discharged into the ecosystem from stormwater retention structures.

More recently, biofiltration systems have been developed (Davis, 2005, 2007). Research to date suggests that planted retention structures such as planted constructed wetland and rain gardens are more efficient in removing nutrients than unplanted structures (Henderson et al., 2007). Runoff diverted into planted structures is filtered through plants followed by vertical filtration through soil media. In laboratory-scale studies, planted mesocosms (laboratory ecosystems that simulate the structure and components of natural ecosystems) removed $63 \%$ to $77 \% \mathrm{~N}$ and $85 \%$ to $94 \%$ P from synthetic stormwater, whereas nutrient leaching was observed from unplanted mesocosms (Henderson et al., 2007). In field-scale studies, $50 \%$ to $70 \%$ nitrate reduction was accomplished by planting Pontederia cordata in subsurface constructed wetlands (DeBusk et al., 1995), and $30 \%$ to $70 \%$ total $\mathrm{P}$ was removed by planted stormwater ponds (Ou et al., 2006).

However, plants are also a source of nutrients in natural and constructed wetlands, and their role in stormwater mitigation can change from effective removal to consistent leaching (Hatt et al., 2009). Rapid and substantial decomposition and release of organic matters were found in wetland plants after a growing season. Odum and Heywood (1978) quantified that $40 \%$ to $50 \%$ biomass in Pontederia cordata, Sagittaria lancifolia, and Peltandra virginica was released in $10 \mathrm{~d}$ and $70 \%$ to $80 \%$ biomass was released in $60 \mathrm{~d}$ to the water. Therefore, whole plant removal or harvesting shoot biomass is necessary, and in some cases critical, to maintain the performance of stormwater treatment structures. Cutting experiments suggest that removal of shoot biomass in population management applications should be based on the available carbohydrate reserves in the rhizomatous tissues (Granéli et al., 1992), and decomposition models of several emergent aquatic perennial macrophytes were able to identify the optimum timing for shoot harvesting to minimize detrimental influence on plant growth in subsequent seasons (Asaeda et al., 2008).

The use of floating wetlands (also called floating islands) for stormwater mitigation is relatively new, although floating biofiltration techniques have been used to remove excess $\mathrm{N}$ in fish farms (Crab et al., 2007). Studies in a wastewater treatment pond and a laboratory-scale constructed wetland suggest that the use of floating systems increases mitigation capacity and provides efficient $\mathrm{N}$ and $\mathrm{P}$ removal that is important for small-sized treatment structures in urban areas (Jayaweera and Kasturiarachchi, 2004; Stewart et al., 2008). In addition, when ornamental plants are used, floating systems add aesthetic value to the treatment area and can mutually benefit the community and environment.

Several obligate wetland plant species such as pickerelweed (Pontederia cordata), arrow arum (Peltandra virginica), and bulltongue arrowhead (Sagittaria lancifolia) 
have been studied for nutrient removal abilities in wastewater treatments (DeBusk et al., 1995; Hadad et al., 2006; Read et al., 2008; Srivastava et al., 2008). However, few studies have quantified the nutrient removal ability of wetland species in a floating system. A few aquatic ornamental plants have been studied for wastewater (Belmont and Metcalfe, 2003; Wolverton, 1990) and nursery runoff treatments (Polomski et al., 2007) in laboratory-scale subsurface constructed wetlands. However, little data exist on nutrient removal and survivability of these ornamental plants in floating systems (Miyazaki et al., 2004; Stewart et al., 2008).

In this study, the following ornamental plants were chosen as biofiltration candidate plants: canna (Canna ×generalis Bailey) 'Australia', iris (Iris pseudacorus L.) 'Golden Fleece', calla lily [Zantedeschia aethiopica (L.) Spreng], and dwarf papyus (Cyperus haspan L.). Besides their potential of nutrient removal, they were chosen also because they are aesthetically attractive, able to thrive in water, and are noninvasive. Three obligate wetland species, pickerelweed, arrow arum, and bulltongue arrowhead, were chosen as reference species because they have been widely used in wastewater treatments. All of these plants are herbaceous perennials in areas above zone 5 of the USDA plant hardiness zone map. Herbaceous perennials are desirable for floating systems because their aboveground biomass can be harvested by the end of a growing season to avoid releasing nutrients back into the water, and new growth will begin the next season to continue removing nutrients from the water.

A hydroponic nutrient recirculation system (NRS) was used for this study. The water dynamics in this system are similar to retention ponds or constructed wetlands that receive stormwater inflows from time to time. The design of the plant growth container of the NRS units simulates the growing condition of a floating system (Chen et al., 2008). In addition, the design of the NRS allows us to quantify the amounts of water and nutrients provided to individual units throughout the growing season and the nutrients remaining in the system at the final harvest.

The objectives of this study were to quantify 1) the nutrient removal abilities of the four ornamental plant species and three obligate wetland species through aboveground biomass harvest; and 2) the nutrient reduction in the NRS units planted with these species under relatively high levels of total $\mathrm{N}$ and $\mathrm{P}$ concentrations found in stormwater treatment structures.

\section{Materials and Methods}

The nutrient recirculation system. Three greenhouse experiments were conducted in a NRS at the Louisiana State University Agricultural Center Hammond Research Station from 2005 to 2007. The NRS was an improved design based on a system built at the University of California, Riverside (Chen et al., 2008). The NRS includes six identical units, each of which was an independent hydroponic recirculation unit providing 284 $\mathrm{L}$ of treatment solution to six plant growth containers. The units were considered replications and the plant growth containers were considered subsamples in the experimental design of this research.

Each plant growth container $(53 \mathrm{~cm}$ wide $x$ $38 \mathrm{~cm}$ long $\times 18 \mathrm{~cm}$ deep) had a polyvinyl chloride pipe nipple inserted into a bulkhead fitting on the bottom of the container as a depth controller to keep the water depth inside the container at $10.6 \mathrm{~cm}$ (Chen et al., 2008). Each plant container was covered by a piece of 1-cm thick marine plywood $(39 \times$ $56 \mathrm{~cm}$ ) with one $14.6-\mathrm{cm}$ diameter round hole in the center to hold a net pot. The plastic net pot was round and black with $15.2-\mathrm{cm}$ top o.d. and 12-cm bottom o.d. (American Hydroponics, Arcata, CA). Inert hydroponic potting medium Hydroton expanded clay (General Hydroponics USA, Sebastopol, CA) was used in all experiments. The net pot was supported by the plywood cover and suspended in the plant container. Plant roots were allowed to grow from the net pot into the treatment solution trapped inside the container. This container design simulates the root environment in a floating biofiltration system where plants are planted in and supported by a floating platform (i.e., polyethylene foam by Maryland Aquatic Nurseries, Jarrettsville, MD) with roots growing in the water.

Besides the plant growth containers, each unit consisted of a reservoir tank, a refill tank, an aeration system, and a $\mathrm{pH}$ monitoring system. At the initiation of an experiment, the reservoir tank, refill tank, and plant growth containers were filled with a predetermined solution to simulate polluted stormwater runoff. This solution was pumped from the reservoir tank into a supply line and dripped through emitters to net pots. After flushing through the growing media, the solution flowed through tubing back to the reservoir tank for another cycle. The refill tank was located on a shelf higher than the reservoir tank and treatment solution added to the reservoir tank by gravity. The amount added was monitored by recording solution level inside a transparent plastic sight tube accompanied by a $0.65-\mathrm{m}$ long ruler mounted along the side of each refill tank. Reservoir tank solution $\mathrm{pH}$ was monitored with an inline $\mathrm{pH}$ probe (model 27001-70; Cole-Parmer Instrument Co., Vernon Hills, IL) connected to individual $\mathrm{pH}$ controllers (Alpha $\mathrm{pH} 200$; Eutech Instruments Ltd., Singapore). Solu- tion $\mathrm{pH}$ was adjusted daily by manually adding base $(\mathrm{NaOH})$ or acid $\left(\mathrm{H}_{2} \mathrm{SO}_{4}\right)$ to the reservoir tank to maintain solution $\mathrm{pH}$ at $\approx 6.5$ to avoid possible $\mathrm{P}$ precipitation under alkaline solution $\mathrm{pH}$ levels. An air pump (AirTech 40L; Evolution Aqua Ltd. Wigan, Lancashire UK) supplied air to six air stones (Boyu Industries Co., Ltd., Guangdong, China) so that each aerated the solution constantly in one of the six reservoir tanks. The movement of air bubbles also provides agitation for constantly mixing the solution in the reservoir tank.

All units were controlled simultaneously by an irrigation controller (Sterling 8; Superior Controls Inc., Valencia, CA). In all experiments, units were programmed to operate from 6 AM to 8 PM and run for 40 min every hour as a cycle. In each cycle, the motor valves under the refill tanks were turned on for the first $20 \mathrm{~min}$ to allow the reservoir tanks to be filled with treatment solution to the designed level $(98.3 \mathrm{~L})$. Then the pumps run for $20 \mathrm{~min}$ to circulate the treatment solution among the plant containers within a unit. Temperatures in the greenhouse were set at $26.7{ }^{\circ} \mathrm{C}$ day $/ 18.3{ }^{\circ} \mathrm{C}$ night for all experiments. Actual temperatures and relative humidity were monitored with $\mathrm{HOBO}$ sensors (Onset Computer Corp., Bourne, MA). The average maximum and minimum daily temperatures and the average maximum and minimum daily relative humidity over the time during the three greenhouse experiments are listed in Table 1. Less variation in greenhouse temperature and relative humidity was found among the three experiments conducted from April to June compared with the experiment conducted from October to December in 2005.

Plant preparation. Plants were prepared for transplant following the same procedure in all experiments. 'Australia' canna, 'Golden Fleece' iris, dwarf papyrus, arrow arum, pickerelweed, and bulltongue arrowhead were obtained from Charleston Aquatic Nursery (Johns Island, SC) as liner plants in 4-inch pots. On arriving, plants were removed from their original pots, their roots were washed free of media and controlled-release fertilizers, and then transplanted into 6 -inch round pots $(1.43 \mathrm{~L})$ in perlite. Calla lily bulbs were obtained from Bourgondien \& Son Inc. (Virginia Beach, VA) and planted in 6-inch pots in perlite. Plants were grown under natural photoperiod (lat. $30^{\circ} \mathrm{N}$ ) for 2 weeks and watered once a day with overhead sprinklers. The 2 weeks of growing in an inert media without additional fertilization helped

Table 1. Experiment durations, average daily maximum and minimum temperatures, and average daily maximum and minimum relative humidity in the greenhouse with the nutrient recirculation system during three experiments (with Expt. 1 repeated).

\begin{tabular}{|c|c|c|c|c|c|}
\hline & \multirow[b]{2}{*}{ Duration } & \multicolumn{2}{|c|}{$\begin{array}{c}\text { Avg daily } \\
\text { temperature }\left({ }^{\circ} \mathrm{C}\right)\end{array}$} & \multicolumn{2}{|c|}{$\begin{array}{l}\text { Avg daily relative } \\
\text { humidity }(\%)\end{array}$} \\
\hline & & Maximum & Minimum & Maximum & Minimum \\
\hline \multirow[t]{2}{*}{ Expt. 1} & 12 Apr. to 14 June 2005 & 29.0 & 15.4 & 89.5 & 39.2 \\
\hline & 3 Oct. to 7 Dec. 2005 & 23.6 & 8.6 & 68.1 & 24.5 \\
\hline Expt. 2 & 4 Apr. to 12 June 2006 & 29.4 & 16.4 & 87.9 & 38.4 \\
\hline Expt. 3 & 18 Apr. to 7 June 2007 & 30.9 & 16.4 & 90.4 & 41.1 \\
\hline
\end{tabular}


plants achieve relatively similar nutrient background. Plants were then removed from their pots and roots washed free of perlite. With offshoots removed, a single stand of canna, iris, arrow arum, pickerelweed, and bulltongue arrowhead and clumps of 10 elongated stems of dwarf papyrus were weighed and transplanted into net pots in Hydroton clay. Single calla lily bulbs with side bulbs removed were weighed and planted in a separate net pot in Hydroton clay. We used plant fresh weight to select uniform plants and bulbs. After transplant, net pots were placed in the plant growth containers in NRS.

Treatments. As a result of size limitation of the NRS system, only three species were evaluated in each experiment. Expt. 1 was conducted from 12 Apr. to 14 June 2005 and repeated from 3 Oct. to 7 Dec. 2005; the species evaluated were 'Australia' canna, 'Golden Fleece' iris, and arrow arum. Expt. 2 was conducted from 4 Apr. to 12 June, 2006, and the species evaluated were dwarf papyrus, pickerelweed, and bulltongue arrowhead. 'Australia' canna and pickerelweed showed high nutrient removal ability in Expts. 1 and 2, respectively, and therefore were evaluated again along with calla lily in Expt. 3 from 18 Apr. to 7 June 2007.

In each experiment, a total of 36 plants was transplanted into NRS where each species occupied two units. In all experiments, NRS units were filled with a nutrient solution with total $\mathrm{N}$ concentration at $11.29 \mathrm{mg} \cdot \mathrm{L}^{-1}$ $\left(\mathrm{NO}_{3}-\mathrm{N}: \mathrm{NH}_{4}-\mathrm{N}=3: 1\right)$ and $\mathrm{P}$ concentration at $3.1 \mathrm{mg} \cdot \mathrm{L}^{-1}$ while other nutrients in the solution were kept consistent (Table 2). These N and $\mathrm{P}$ concentrations were within the ranges of inorganic $\mathrm{N}$ and $\mathrm{P}$ concentrations reported in stormwater retention structures (Moustafa, 1999; Serrano and DeLorenzo, 2008). Water source was municipal water filtered through a two-holder B-Pure water purification system housed with a carbon filter and a deionizer filter (D0813 and D0749; Barnstead International, Dubuque, IA).

Data collection. During an experiment, the solution levels in the refill tanks were recorded daily at 1 PM. Daily water consumption of a unit was calculated as the difference between readings of 2 consecutive days. Total solution consumption of a unit was the sum of daily water consumption of a unit throughout an experiment. Total $\mathrm{N}$ and $\mathrm{P}$ provided to a unit were calculated as: (total solution consumption per unit $+284 \mathrm{~L}$ initial fill solution) $\times$ treatment $\mathrm{N}$ or $\mathrm{P}$ concentrations. Water consumed by a unit is a result of plant evapotranspiration and water loss from the surfaces of unit components. Water loss by unit surface evaporation was estimated with the NRS operating with the pots and media in the growth containers but without the plants for 7 consecutive days. An average of $0.03 \pm 0.02 \mathrm{~L}$ daily loss per unit was recorded, which was negligible compared with the amount of plant consumption. Average daily water consumption per plant was then calculated by dividing daily water consumption of a unit by 6 (plants).

Table 2. Chemical formulations and elemental concentrations of the treatment solution in three experiments conducted in a nutrient recirculation system (NRS).

\begin{tabular}{|c|c|c|c|}
\hline \multicolumn{4}{|c|}{ Nutrient solution formulations } \\
\hline Chemical & Molecular mass $\left(\mathrm{g} \cdot \mathrm{M}^{-1}\right)$ & $\begin{array}{l}\text { Stock solution } \\
\text { concn (mM) }\end{array}$ & To use $\left(\mathrm{mL} \cdot \mathrm{L}^{-1}\right)$ \\
\hline \multicolumn{4}{|c|}{ Macronutrients } \\
\hline $\mathrm{NH}_{4} \mathrm{NO}_{3}$ & 80.04 & 1,000 & 0.2 \\
\hline $\mathrm{Ca}\left(\mathrm{NO}_{3}\right)_{2} \cdot 4 \mathrm{H}_{2} \mathrm{O}$ & 236.15 & 1,000 & 0.2 \\
\hline $\mathrm{KH}_{2} \mathrm{PO}_{4}$ & 136.08 & 1,000 & 0.1 \\
\hline $\mathrm{K}_{2} \mathrm{SO}_{4}$ & 174.25 & 500 & 0.25 \\
\hline $\mathrm{CaCl}_{2} \cdot 2 \mathrm{H}_{2} \mathrm{O}$ & 147.02 & 1,000 & 0.6 \\
\hline $\mathrm{MgSO}_{4} \cdot 7 \mathrm{H}_{2} \mathrm{O}$ & 246.5 & 1,000 & 0.5 \\
\hline \multicolumn{4}{|c|}{ Micronutrients (mixed in 1-gallon container) } \\
\hline EDTA-Fe & 367.10 & 100 & 0.04 \\
\hline $\mathrm{H}_{3} \mathrm{BO}_{3}$ & 61.83 & 100 & $0.27^{\mathrm{z}}$ \\
\hline $\mathrm{MnCl}_{2} \cdot 4 \mathrm{H}_{2} \mathrm{O}$ & 197.91 & 10 & \\
\hline$\left(\mathrm{NH}_{4}\right)_{6} \mathrm{Mo}_{7} \mathrm{O}_{24} \cdot 4 \mathrm{H}_{2} \mathrm{O}$ & $1,235.86$ & 1 & \\
\hline $\mathrm{ZnSO}_{4} \cdot 7 \mathrm{H}_{2} \mathrm{O}$ & 287.54 & 1 & \\
\hline $\mathrm{CuSO}_{4} \cdot 5 \mathrm{H}_{2} \mathrm{O}$ & 249.68 & 1 & \\
\hline \multicolumn{4}{|c|}{ Elemental concentrations $\left(\mathrm{mg} \cdot \mathrm{L}^{-1}\right)$} \\
\hline Element & Concn & & \\
\hline $\mathrm{NH}_{4}-\mathrm{N}$ & 2.89 & & \\
\hline $\mathrm{NO}_{3}-\mathrm{N}$ & 8.40 & & \\
\hline Total N & 11.29 & & \\
\hline Phosphorus & 3.10 & & \\
\hline Potassium & 23.46 & & \\
\hline Sulfur & 24.10 & & \\
\hline Calcium & 32.06 & & \\
\hline Magnesium & 12.15 & & \\
\hline Iron & 2.23 & & \\
\hline Manganese & 0.55 & & \\
\hline Copper & 0.05 & & \\
\hline Boron & 0.54 & & \\
\hline Zinc & 0.05 & & \\
\hline Molybdenum & 0.67 & & \\
\hline Chloride & 36.16 & & \\
\hline
\end{tabular}

${ }^{\mathrm{z}}$ Micronutrients $\mathrm{B}, \mathrm{Mn}, \mathrm{Mo}, \mathrm{Zn}$, and $\mathrm{Cu}$ were prepared in one solution and used at $0.27 \mathrm{~mL} \cdot \mathrm{L}^{-1}$.

Water samples of $100 \mathrm{~mL}$ solution were collected from the reservoir tanks between 1 PM and 4 PM into acid-washed Nalgene bottles every $7 \mathrm{~d}$. Each sample was filtered through $0.2-\mathrm{mm}$ polytetrafluoroethylene membrane filters into two $50-\mathrm{mL}$ water sample bottles. One bottle of the sample was acidified with $2 \mathrm{~mL}$ of sulfuric acid ( $2 \mathrm{~N})$ to chemically stabilize the sample and stored at $4{ }^{\circ} \mathrm{C}$. Another bottle of the sample was not acidified and sent for nitrate and nitrite analyses at the EPA-approved water analysis laboratory at the Louisiana State University AgCenter Department of Agricultural Chemistry. At the end of an experiment, all acidified samples were analyzed to determine total $\mathrm{P}$ and ammonia concentrations. Total $\mathrm{P}$ was determined by colorimetric analysis (EPA 365.3; EPA, 1983). Ammonia was determined by the SM4500-NH3_E method. Nitrate and nitrite concentrations were determined by ion chromatography (EPA 300.0; EPA, 1983).

Plants were harvested after being grown in the NRS for 10 weeks. Plants were removed from the net pots and weighed for fresh weight. Shoots (including inflorescences), rhizomes, and roots were washed in municipal water for $30 \mathrm{~s}$. Rhizomes of arrow arum, iris, and calla lily were sliced into thin pieces. All samples were dried at $70{ }^{\circ} \mathrm{C}$ until weight became constant to determine dry weight. Dried tissue sample was ground in a Wiley Mill (Swedesboro, NJ) to pass through 40-mesh $(0.425 \mathrm{~mm})$ screen. Tissue analyses were conducted by Louisiana State University Soil Testing and Plant Analysis Laboratory. Tissue $\mathrm{N}$ concentration was determined by an LECO TruSpec CN nitrogen analyzer (LECO, St. Joseph, MI).

Statistical analyses. The experimental design was randomized complete block design with three treatments (species) and two blocks (NRS units) for all experiments. The NRS units were arranged parallel to the greenhouse cooling pads so that blocking accounted for the temperature gradient in the greenhouse. The six plants, each in a growth container within a unit, were subsamples. Expt. 1 was repeated and data were pooled because no significant difference was found between the two experiments. Analyses of variance was performed to test treatment (species) significance in each experiment with $\alpha=0.05$. Fisher's protected least significant difference was used to separate means. Analyses were conducted using SAS Version 9.1.3 (SAS Institute, Cary, NC).

\section{Results and Discussion}

Plant water consumption. Daily water consumption fluctuated throughout the three experiments (Fig. 1). Canna had the greatest daily water consumption in Expt. 1 (1.4 L per plant per day; Fig. 1A). At Week 10, canna consumed an average of fourfold more water than arrow arum and fivefold more water than iris. In Expt. 2, pickerelweed (1.1 L per plant 
A

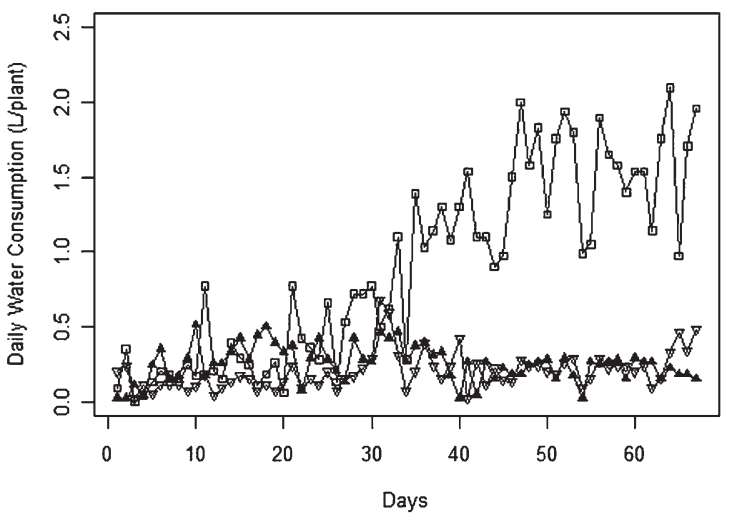

C

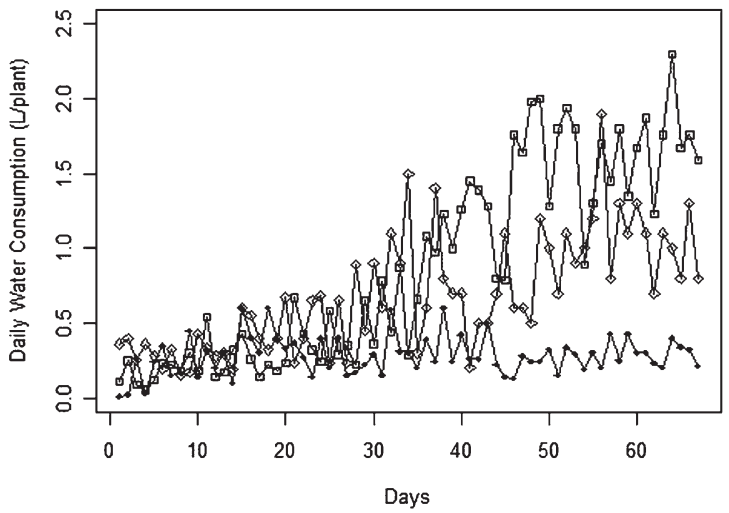

B

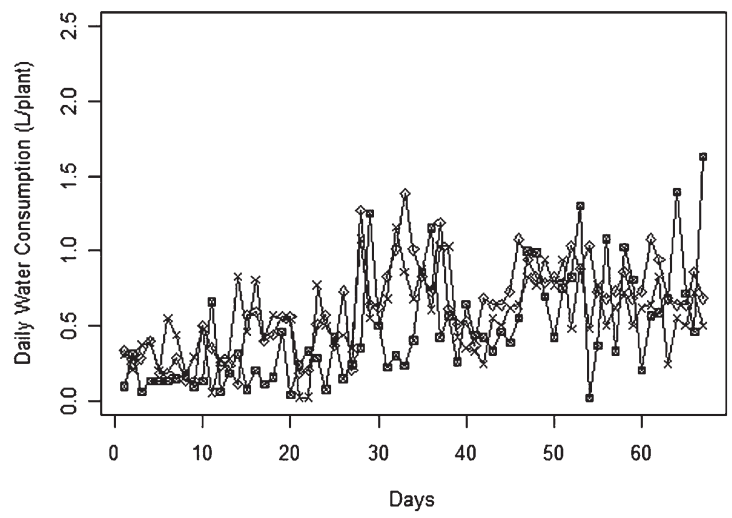

口 'Australia' canna

$\checkmark$ 'Golden Fleece' iris

- Arrow arum

¿ Dwarf papyrus

$\diamond$ Pickerelweed

$\times$ Bulltongue arrowhead

- Calla lily

Fig. 1. Daily water consumption of four ornamental plants compared with three wetland species commonly used in stormwater treatment in three experiments conducted in a nutrient recirculation system (NRS) from 2005 to 2007 . The six units of the NRS were planted with three plant species in each experiment. (A) 'Australia' canna, 'Golden Fleece' iris, and arrow arum in Expt. 1. (B) Dwarf papyrus, pickerelweed, and bulltongue arrowhead in Expt. 2. (C) 'Australia' canna, calla lily, and pickerelweed in Expt. 3.

per day; Fig. 1B) consumed more water than dwarf papyrus ( $0.67 \mathrm{~L}$ per plant per day) and bulltongue arrowhead $(0.71 \mathrm{~L}$ per plant per day). In Expt. 3, water consumption by canna was the greatest, followed by pickerelweed, and with calla lily having the least water consumption (Fig. 1C). Our results are similar to those reported from a laboratory-scale wetland study (Polomski et al., 2007), in which canna and pickerelweed had greater water consumption than other species. However, 'GoldenFleece' iris in our study consumed much less water than hybrid Louisiana iris 'Full Eclipse' in their study, indicating a possible difference between iris cultivars.

Biomass accumulation. At harvest, 'Australia' canna accumulated the greatest total biomass as indicated by plant dry weight compared with arrow arum and iris (Table 3 ). When using shoot dry weight as an indication of harvestable biomass, canna accumulated $\approx 10$ - and 15 -fold more harvestable biomass than arrow arum and iris, respectively. In Expt. 2, pickerelweed and dwarf papyrus had similar total biomass, but the former had greater harvestable biomass. In Expt. 3, canna had more total and harvestable biomass than pickerelweed. Because calla lily bulbs had considerably higher initial biomass than single plants of canna and pickerelweed, we did not compare the biomass production of calla
Table 3. Dry weight of the shoots, rhizomes, and roots of ornamental and wetland plants grown for 10 weeks in a greenhouse nutrient recirculation system with total nitrogen and phosphorous concentrations of 11.29 and $3.1 \mathrm{mg} \cdot \mathrm{L}^{-1}$ in three experiments conducted from 2005 to 2007.

\begin{tabular}{|c|c|c|c|c|}
\hline \multirow[b]{2}{*}{ Species } & \multicolumn{4}{|c|}{ Dry wt (g) } \\
\hline & Shoot & Rhizome $^{z}$ & Root & Total \\
\hline \multicolumn{5}{|c|}{ Expt. $1^{y}$} \\
\hline Canna & $89 a^{x}(83 \%)^{w}$ & $9.22(8 \%)$ & 9.36 a $(9 \%)$ & $107.58 \mathrm{a}$ \\
\hline Arrow arum & 8.96 b (49\%) & $6.03(33 \%)$ & $3.41 \mathrm{~b}(18 \%)$ & $18.4 \mathrm{~b}$ \\
\hline Iris & $5.83 \mathrm{~b}(44 \%)$ & $4(30 \%)$ & $3.4 \mathrm{~b}(26 \%)$ & $13.23 \mathrm{~b}$ \\
\hline $\mathrm{LSD}_{0.05}$ & 11.7 & $\mathrm{NS}^{\mathrm{v}}$ & 2.20 & 17.93 \\
\hline \multicolumn{5}{|c|}{ Expt. 2} \\
\hline Pickerelweed & 56.12 a $(84 \%)$ & $2.4(3 \%)$ & $8.53(13 \%)$ & 67.05 \\
\hline Dwarf papyrus & $43.07 \mathrm{~b}(86 \%)$ & - & $7.18(14 \%)$ & 50.25 \\
\hline Bulltongue arrowhead & $42.85 \mathrm{~b}(84 \%)$ & - & $8.33(16 \%)$ & 51.18 \\
\hline $\operatorname{LSD}_{0.05}$ & 13 & - & NS & NS \\
\hline \multicolumn{5}{|c|}{ Expt. $3^{u}$} \\
\hline Canna & 78.8 a $(78 \%)$ & $11.8(11 \%)$ & $10.5(11 \%)$ & $101.1 \mathrm{a}$ \\
\hline Pickerelweed & 51.9 b $(84 \%)$ & $3(5 \%)$ & $6.5(11 \%)$ & $61.4 \mathrm{~b}$ \\
\hline $\operatorname{LSD}_{0.05}$ & 14.5 & NS & NS & 21.8 \\
\hline
\end{tabular}

${ }^{\mathrm{z}}$ Because dwarf papyrus and bulltongue arrowhead did not form harvestable rhizomes during the 10-week growth period, data for rhizome were not available.

${ }^{y}$ Expt. 1 was repeated and data were pooled because no significant difference was found between the two experiments. Initial biomass of the plant species evaluated in Expts. 1 and 2 were similar as indicated by plant fresh weight measured at transplant (data not presented).

${ }^{x}$ Means within a variable column of an experiment not followed by the same letter are significantly different by Fisher's protected least significant difference (LSD). $\alpha=0.05 . \mathrm{N}=24$ in Expt. 1 and $\mathrm{N}=12$ in Expts. 2 and 3.

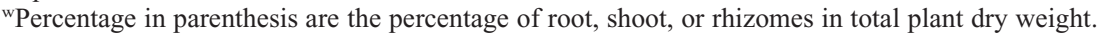

vTreatment (species) effect was nonsignificant (NS) $(P>0.05)$.

"Calla lily was not included in the comparison of plant dry weight in Expt. 3 because the initial biomass of calla lily bulbs was significantly higher than the biomass of canna and pickerelweed as indicated by plant fresh weight measured at transplant (data not presented). 
lily with the other species in Expt. 3. Canna and pickerelweed were also reported as having high biomass production in other studies (Belmont and Metcalfe, 2003; Polomski et al., 2007).

Within the 10-week period of growth, all plants except dwarf papyrus and bulltongue arrowhead had rhizomatous underground tissue. There was a significant difference among species in terms of above-/underground biomass allocation. For example, in Expt. 1, $80 \%$ of the total biomass in canna was aboveground and thus harvestable. On contrast, only $48.7 \%$ of the total biomass in arrow arum and $44.1 \%$ in iris were harvestable because underground rhizomes alone accounted for $32.8 \%$ and $30.2 \%$ of the total biomass in these species, respectively (Table 3 ).

Plant tissue nutrient concentration. Plant tissue nutrient concentrations are often reported in water mitigation studies to compare plant nutrient removal ability. In our study, canna, iris, pickerelweed, and bulltongue arrowhead had higher $\mathrm{N}$ concentrations in shoots than in rhizomes and roots (Table 4). Nitrogen tissue concentrations in canna, iris, and pickerelweed in our study were higher than those reported by Polomski et al. (2007) in which different cultivars of these species were grown in $10.44 \mathrm{mg} \cdot \mathrm{L}^{-1} \mathrm{~N}$ and $1.86 \mathrm{mg} \cdot \mathrm{L}^{-1} \mathrm{P}$, suggesting that plants may use more $\mathrm{N}$ at higher $\mathrm{P}$ loading rates.

Tissue $\mathrm{P}$ concentration was generally higher in shoots than roots with canna and arrow arum (Expt. 1), pickerelweed, and bulltongue arrowhead (Expt. 2) having higher tissue $\mathrm{P}$ concentrations than other species. Phosphorus concentrations in canna in our study were also higher than those reported by other studies with similar P treatment levels but different cultivars (DeBusk et al., 1995; Hadad and Maine, 2007; Polomski et al., 2007). Phosphorous concentration in bulltongue arrowhead was also higher than a natural population (Richards and Ivey, 2004) suggesting luxury consumption of $\mathrm{P}$ in our study.

Plant tissue nutrient content. Because of greater shoot biomass accumulation, canna and pickerelweed had higher shoot $\mathrm{N}$ and $\mathrm{P}$ content than other species in Expts. 1 and 2, respectively (Table 5). As a result, when comparing nutrient allocation among shoot, rhizome, and root, a higher percentage of $\mathrm{N}$ and $\mathrm{P}$ content was found in shoots of canna ( $86 \%$ total $\mathrm{N}$ and $89 \%$ of total $\mathrm{P}$ ) and pickerelweed ( $85 \%$ total $\mathrm{N}$ and $89 \%$ total $\mathrm{P})$. On contrast, arrow arum and iris had significantly higher percentages of total $\mathrm{N}$ and $\mathrm{P}$ content in rhizomes, and only $48.7 \%$ and $59.1 \%$ total $\mathrm{N}$ content and $64.2 \%$ and $68.1 \%$ total $\mathrm{P}$ content were in shoots. Species with higher shoot $\mathrm{N}$ and $\mathrm{P}$ content such as canna and pickerelweed are desired because shoot biomass can be harvested by the end of a growing season(s) to remove nutrient from the treatment system.

Nutrient concentrations in the nutrient recirculation system units. By analyzing $\mathrm{N}$ (ammonium and nitrate) and $\mathrm{P}$ (total $\mathrm{P}$ ) concentrations in solution samples collected

Table 4. Tissue nitrogen $(\mathrm{N})$ and phosphorous $(\mathrm{P})$ concentrations in shoots, rhizomes, and roots of ornamental and wetland plants grown for 10 weeks in a greenhouse nutrient recirculation system with total $\mathrm{N}$ and $\mathrm{P}$ concentrations of 11.29 and $3.1 \mathrm{mg} \cdot \mathrm{L}^{-1}$ in three experiments conducted from 2005 to 2007.

\begin{tabular}{|c|c|c|c|c|c|c|}
\hline \multirow[b]{2}{*}{ Species } & \multicolumn{3}{|c|}{$\mathrm{N}$ concn $(\%$ dry wt $)$} & \multicolumn{3}{|c|}{$\mathrm{P}$ concn $(\%$ dry wt) } \\
\hline & Shoot & Rhizome $^{z}$ & Root & Shoot & Rhizome & Root \\
\hline \multicolumn{7}{|c|}{ Expt. $1^{y}$} \\
\hline Canna & $1.51 \mathrm{~b}^{\mathrm{x}}$ & $0.91 \mathrm{c}$ & 1.25 & $0.44 \mathrm{ab}$ & 0.11 & 0.18 \\
\hline Arrow arum & $1.32 \mathrm{~b}$ & $1.31 \mathrm{~b}$ & 1.33 & $0.53 \mathrm{a}$ & 0.27 & 0.30 \\
\hline Iris & $2.72 \mathrm{a}$ & $1.7 \mathrm{a}$ & 1.23 & $0.39 \mathrm{~b}$ & 0.13 & 0.16 \\
\hline $\mathrm{LSD}_{0.05}$ & 0.33 & 0.21 & $\mathrm{NS}^{\mathrm{w}}$ & 0.09 & NS & NS \\
\hline \multicolumn{7}{|c|}{ Expt. 2} \\
\hline Pickerelweed & $1.78 \mathrm{~b}$ & 1.05 & $1.65 \mathrm{ab}$ & $0.51 \mathrm{a}$ & 0.22 & 0.24 \\
\hline Dwarf papyrus & $1.61 \mathrm{~b}$ & - & $1.82 \mathrm{a}$ & $0.37 \mathrm{~b}$ & - & 0.21 \\
\hline Bulltongue arrowhead & $2.1 \mathrm{a}$ & - & $1.4 \mathrm{~b}$ & $0.50 \mathrm{a}$ & - & 0.19 \\
\hline $\mathrm{LSD}_{0.05}$ & 0.27 & - & 0.22 & 0.13 & - & NS \\
\hline \multicolumn{7}{|c|}{ Expt. $3^{v}$} \\
\hline Canna & 1.86 & 1.12 & 1.29 & 0.41 & 0.17 & 0.34 \\
\hline Pickerelweed & 1.95 & 1.31 & 1.54 & 0.48 & 0.18 & 0.22 \\
\hline $\mathrm{LSD}_{0.05}$ & NS & NS & NS & NS & NS & NS \\
\hline
\end{tabular}

${ }^{\mathrm{z}}$ Because dwarf papyrus and bulltongue arrowhead did not form harvestable rhizomes during the 10-week growth period, data for rhizome were not available.

${ }^{y}$ Expt. 1 was repeated and data were pooled because no significant difference was found between the two experiments.

${ }^{x}$ Means within a variable column of an experiment not followed by the same letter are significantly different by Fisher's protected least significant difference (LSD). $\alpha=0.05 . \mathrm{N}=24$ in Expt. 1 and $\mathrm{N}=12$ in Expts. 2 and 3.

wTreatment (species) effect was nonsignificant (NS) $(P>0.05)$.

vBecause the biomass (and possibly nutrient contents) in calla lily bulbs was significantly higher than canna and pickerelweed as indicated by plant fresh weight at the initiation of the experiment (data not presented). It is possible that tissue $\mathrm{N}$ and $\mathrm{P}$ concentrations may be affected by the nutrient reallocation from bulbs to shoots and roots. Therefore, $\mathrm{N}$ and $\mathrm{P}$ concentrations in calla lily were not compared in Expt. 3.

Table 5. Tissue nitrogen $(\mathrm{N})$ and phosphorous $(\mathrm{P})$ contents of the shoots, rhizomes, and roots of ornamental and wetland plants grown for 10 weeks in a greenhouse nutrient recirculation system with total nitrogen and phosphorous concentrations of 11.29 and $3.1 \mathrm{mg} \cdot \mathrm{L}^{-1}$ in three experiments conducted from 2005 to 2007.

\begin{tabular}{|c|c|c|c|c|c|c|}
\hline \multirow[b]{2}{*}{ Species } & \multicolumn{3}{|c|}{$\mathrm{N}$ content (mg/plant) } & \multicolumn{3}{|c|}{$\mathrm{P}$ content (mg/plant) } \\
\hline & Shoot & Rhizome $^{z}$ & Root & Shoot & Rhizome & Root \\
\hline \multicolumn{7}{|c|}{ Expt. $1^{y}$} \\
\hline Canna & $1,343.9 \mathrm{a}^{\mathrm{x}}$ & 83.9 & $117 \mathrm{a}$ & $391.6 \mathrm{a}$ & $10.1 \mathrm{a}$ & $16.8 \mathrm{a}$ \\
\hline Arrow arum & $118.3 \mathrm{~b}$ & 52.8 & $72 \mathrm{~b}$ & $47.5 \mathrm{~b}$ & $10.9 \mathrm{a}$ & $16.2 \mathrm{a}$ \\
\hline Iris & $158.6 \mathrm{~b}$ & 68 & $41.8 \mathrm{~b}$ & $22.7 \mathrm{c}$ & $5.2 \mathrm{~b}$ & $5.4 \mathrm{~b}$ \\
\hline $\operatorname{LSD}_{0.05}$ & 135.1 & $\mathrm{NS}^{\mathrm{w}}$ & 43.55 & 22 & 4.5 & 2.6 \\
\hline \multicolumn{7}{|c|}{ Expt. 2} \\
\hline Pickerelweed & $998.9 \mathrm{a}$ & 25.2 & 140.8 & $286.2 \mathrm{a}$ & 5.3 & 20.5 \\
\hline Dwarf papyrus & $693.4 \mathrm{c}$ & - & 130.7 & $168.2 \mathrm{~b}$ & - & 15.1 \\
\hline Bulltongue arrowhead & $899.9 \mathrm{~b}$ & - & 116.6 & $214.3 \mathrm{~b}$ & - & 15.8 \\
\hline $\operatorname{LSD}_{0.05}$ & 98.6 & - & NS & 69.6 & - & NS \\
\hline \multicolumn{7}{|c|}{ Expt. $3^{v}$} \\
\hline Canna & $1,465.7 \mathrm{a}$ & $132.2 \mathrm{a}$ & 135.5 & $323.1 \mathrm{a}$ & $20.1 \mathrm{a}$ & $35.7 \mathrm{a}$ \\
\hline Pickerelweed & $1,012.1 \mathrm{~b}$ & $39.3 \mathrm{~b}$ & 100.1 & $249.1 \mathrm{~b}$ & $5.4 \mathrm{~b}$ & $14.3 \mathrm{~b}$ \\
\hline $\mathrm{LSD}_{0.05}$ & 79.5 & 66.3 & NS & 60.07 & 12.9 & 17.6 \\
\hline
\end{tabular}

${ }^{\mathrm{z} B e c a u s e}$ dwarf papyrus and bulltongue arrowhead did not form harvestable rhizomes during the 10-week growth period, data for rhizome were not available.

${ }^{y}$ Expt. 1 was repeated and data were pooled because no significant difference was found between the two experiments.

${ }^{\mathrm{x}}$ Means within a variable column of an experiment not followed by the same letter are significantly different by Fisher's protected least significant difference (LSD). $\alpha=0.05 . \mathrm{N}=24$ in Expt. 1 and $\mathrm{N}=12$ in Expts. 2 and 3.

wreatment (species) effect was nonsignificant (NS) $(P>0.05)$.

${ }^{v}$ Calla lily was not included in the comparison of tissue $\mathrm{N}$ and $\mathrm{P}$ contents in Expt. 3 because the biomass (and possibly nutrient contents) of calla lily bulbs was significantly higher than canna and pickerelweed as indicated by plant fresh weight at the initiation of the experiment (data not presented).

every week, we quantified plant nutrient removal ability from the perspective of system nutrient reduction. Nitrate and ammonium were provided in treatment solution at a 3:1 ratio preferred by most plant species (Marschner, 1995). At Week 10, ammonium $\left(\mathrm{NH}_{4}^{+}\right) \mathrm{N}$ was undetectable (less than 0.03 $\mathrm{mg} \cdot \mathrm{L}^{-1}$ ) in all unit solutions. This was expected because other than plant uptake, nitrification of $\mathrm{NH}_{4}{ }^{+}$to $\mathrm{NO}_{3}{ }^{-}$could decrease its concentration. In all experiments, nitrate concentration of treatment solution remaining in NRS units fluctuated and generally declined over the second half of the experiments. 

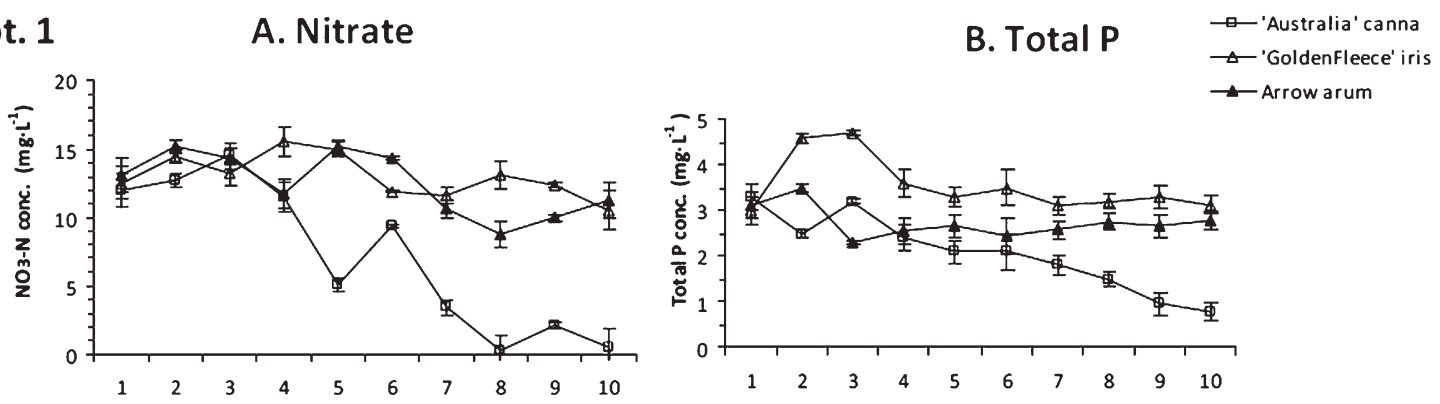

Expt. 2
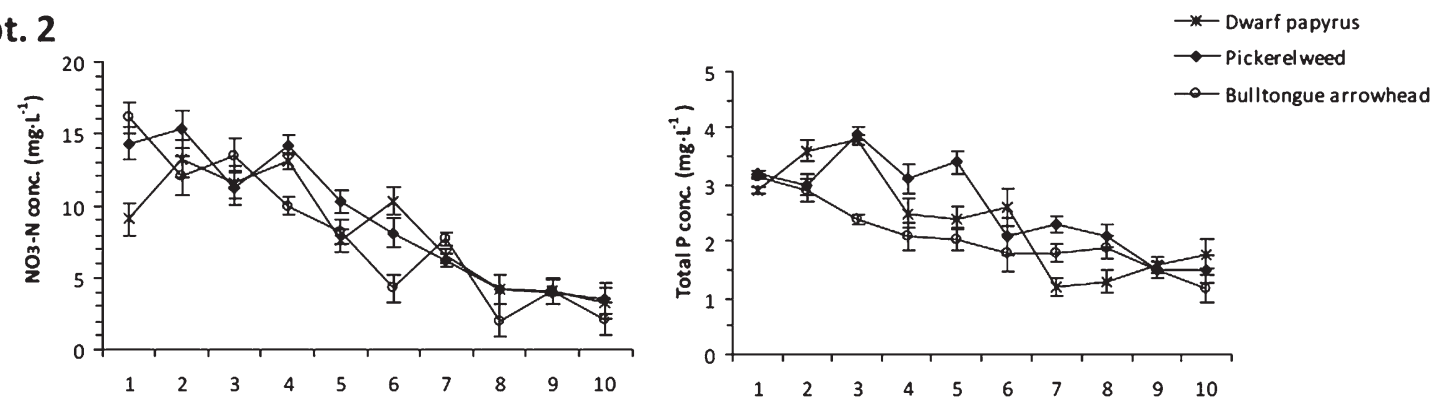

Expt. 3
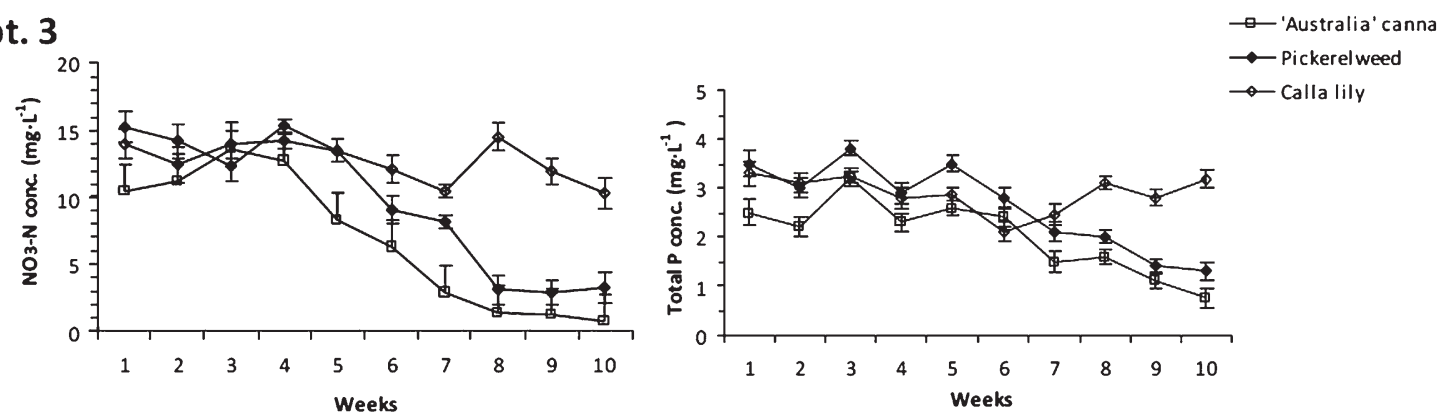

Fig. 2. Nitrate-N (A) and total phosphorus (P) (B) concentrations in weekly solution samples taken from a nutrient recirculation system (NRS) planted with ornamental or wetland species in three experiments. Plant species evaluated in Expt. 1 were 'Australia' canna, arrow arum, and 'GoldenFleece' iris. Species evaluated in Expt. 2 were pickerelweed, dwarf papyrus, and bulltongue arrowhead. Species evaluated in Expt. 3 were 'Australia' canna, pickerelweed, and calla lily. Nitrate and total P concentrations were $8.4 \mathrm{mg} \cdot \mathrm{L}^{-1}$ and $3.1 \mathrm{mg} \cdot \mathrm{L}^{-1}$, respectively, in the original treatment and refill solutions.

From Weeks 5 to 10 , nitrate concentrations in units planted with canna (Fig. 2A, Expt. 1) was lower than those in other units at every sample dates. Nitrate concentrations in units planted with pickerelweed, dwarf papyrus, and bulltongue arrowhead declined over time. However, nitrate concentrations in units planted with iris, arrow arum (Fig. 2A, Expt. 1), and calla lily (Fig. 2A, Expt. 3) remained high at the end of Expts. 1 and 3, respectively.

Total P concentrations of nutrient solutions remaining in units planted with canna (Fig. 2B, Expt. 1), pickerelweed, dwarf papyrus, and bulltongue arrowhead (Fig. 2B, Expt. 2) declined with time during the experiments. Units planted with iris, arrow arum, and calla lily had significantly higher solution $\mathrm{P}$ than other units at Week 10 in Expts. 1 and 3. Because $\mathrm{P}$ concentration used in our study was close to the highest concentrations found in stormwater retention structure, it is likely that this concentration exceeded the uptake ability of some plant species and resulted in luxury consumption of $\mathrm{P}$. This was also suggested by Zhang et al. (2008), that when $\mathrm{P}$ availability in water exceeds plant uptake and assimilation capacity, soil and filter media of the treatment structure become more effective than plants in P removal from the water column.

Total nitrogen and phosphorus removal from the nutrient recirculation system units. Over the 10-week period, we did not observe foliage or root senescence that may return plant tissue into the unit and decompose. Total $\mathrm{N}$ and $\mathrm{P}$ removed by a NRS unit were calculated based on $\mathrm{N}$ and $\mathrm{P}$ remaining in the unit and the $\mathrm{N}$ and $\mathrm{P}$ received throughout the experiments. In addition to plant uptake, potting media adsorption and micro-organism and algae denitrification can also remove $\mathrm{N}$ and $\mathrm{P}$ from the NRS. Because plant uptake has been reported to be the major nutrient removal mechanisms in planted constructed wetlands (Zhang et al., 2007), we did not quantify other possible removal pathways in this study. Instead, final system recovery rate was calculated as percentage of nutrient removed by plants and all possible other mechanisms out of total nutrients received. The units planted with canna received the greatest nutrients than units planted with other species in Expt. 1, and canna had the highest per unit $\mathrm{N}$ and $\mathrm{P}$ recovery rate and total amount of $\mathrm{N}$ and $\mathrm{P}$ recovered (Table 6). Units planted with pickerelweed had similar $\mathrm{N}$ and $\mathrm{P}$ recovery rate as canna in Expt. 3 but a less amount of $\mathrm{N}$ and $\mathrm{P}$ was recovered because a less amount of solution was "processed." Units planted with arrow arum and iris in Expt. 1 and calla lily in Expt. 3 had the lowest $\mathrm{N}$ and $\mathrm{P}$ recovery rate and the least amount of $\mathrm{N}$ and $\mathrm{P}$ removed. High $\mathrm{N}$ and $\mathrm{P}$ recovery rates of canna found in our study are similar to that of other hybrid canna and Canna indica reported by laboratory-scale studies (Zhang et al., 2007; Zurita et al., 2006), but higher than a field pilot-scale studies (Ayaz and Akca, 2001; Tuncsiper et al., 2005). The optimum growing condition in the greenhouse could have contributed to the superior plant growth and nutrient removal in greenhouse studies. Performance of calla lily was similar to that found in a laboratoryscale constructed wetland study where higher $\mathrm{N}$ and $\mathrm{P}$ treatment concentrations were used (Belmont and Metcalfe, 2003).

The objective of this study was to assess the feasibility of using ornamental plant species to remove nutrient pollutions from stormwater treatment structures. Compared with obligate wetland species arrow arum (Expt. 1) and pickerelweed (Expt. 3), 'Australia' canna had great potential to be used as nutrient biofiltration plants in stormwater mitigation attributed to its high biomass 
Table 6. Total nutrient solution consumption, nitrogen $(\mathrm{N})$ and phosphorous $(\mathrm{P})$ received, recovered, and the $\mathrm{N}$ and $\mathrm{P}$ recovery by the nutrient recirculation system (NRS) units planted with ornamental and wetland plants in three experiments conducted from 2005 to 2007.

\begin{tabular}{|c|c|c|c|c|c|c|c|}
\hline \multirow[b]{2}{*}{ Species } & \multirow{2}{*}{$\begin{array}{c}\text { Solution } \\
\text { consumption }^{\mathrm{y}} \text { (L/unit) }\end{array}$} & \multicolumn{2}{|c|}{ Nutrient received $^{\mathrm{x}}$ (mg/unit) } & \multicolumn{2}{|c|}{ Nutrient recovered ${ }^{\mathrm{w}}$ (mg/unit) } & \multicolumn{2}{|c|}{ Nutrient recovery rate $^{\mathrm{v}}(\%)$} \\
\hline & & $\mathrm{N}$ & $\mathrm{P}$ & $\mathrm{N}$ & $\mathrm{P}$ & $\mathrm{N}$ & $\mathrm{P}$ \\
\hline \multicolumn{8}{|c|}{ Expt. $1^{u}$} \\
\hline Canna & $590.9 \mathrm{a}^{\mathrm{t}}$ & $9,877.6 \mathrm{a}$ & $2,712.2 \mathrm{a}$ & $9,749.2 \mathrm{a}$ & $2,489.8 \mathrm{a}$ & $98.7 \mathrm{a}$ & $91.8 \mathrm{a}$ \\
\hline Arrow arum & $129.9 \mathrm{~b}$ & $4,672.9 \mathrm{~b}$ & $1,283.1 \mathrm{~b}$ & $1,476.6 \mathrm{~b}$ & $494.0 \mathrm{~b}$ & $31.6 \mathrm{~b}$ & $38.5 \mathrm{~b}$ \\
\hline Iris & $103.7 \mathrm{~b}$ & $4,377.1 \mathrm{~b}$ & $1,201.9 \mathrm{~b}$ & $1,378.8 \mathrm{~b}$ & $316.1 \mathrm{~b}$ & $31.5 \mathrm{~b}$ & $26.3 \mathrm{~b}$ \\
\hline $\operatorname{LSD}_{0.05}$ & 52.3 & 590.5 & 162.1 & 825.8 & 303.2 & 33.6 & 36.9 \\
\hline \multicolumn{8}{|c|}{ Expt. 2} \\
\hline Pickerelweed & $460 \mathrm{a}$ & $8,399.8 \mathrm{a}$ & $2,306.4 \mathrm{a}$ & $7,400.2 \mathrm{a}$ & $1,877.4 \mathrm{a}$ & 88.1 & 81.4 \\
\hline Dwarf papyrus & $281.3 \mathrm{~b}$ & $6,382.2 \mathrm{~b}$ & $1,752.4 \mathrm{~b}$ & $5,450.4 \mathrm{~b}$ & $1,247.7 \mathrm{c}$ & 85.4 & 71.2 \\
\hline Bulltongue arrowhead & 296 b & $6,548.2 \mathrm{~b}$ & $1,798 \mathrm{~b}$ & $5,939.2 \mathrm{~b}$ & $1,465.4 \mathrm{~b}$ & 90.7 & 81.5 \\
\hline $\mathrm{LSD}_{0.05}$ & 37.5 & 423.4 & 116.3 & $1,070.4$ & 188.6 & $\mathrm{NS}^{\mathrm{s}}$ & NS \\
\hline \multicolumn{8}{|c|}{ Expt. 3} \\
\hline Canna & $596.4 \mathrm{a}$ & $9,939.7 \mathrm{a}$ & $2,729.2 \mathrm{a}$ & $9,711.1 \mathrm{a}$ & $2,516.3 \mathrm{a}$ & $97.7 \mathrm{a}$ & $92.2 \mathrm{a}$ \\
\hline Pickerelweed & $422.3 \mathrm{~b}$ & $7,974.1 \mathrm{~b}$ & $2,189.5 \mathrm{~b}$ & $7,049.1 \mathrm{~b}$ & $1,817.3 \mathrm{~b}$ & $88.4 \mathrm{a}$ & $83 \mathrm{a}$ \\
\hline Calla lily & $113.04 \mathrm{c}$ & $4,482.6 \mathrm{c}$ & $1,230.8 \mathrm{c}$ & $1,560 \mathrm{c}$ & $327.4 \mathrm{c}$ & $34.8 \mathrm{~b}$ & $26.6 \mathrm{~b}$ \\
\hline $\mathrm{LSD}_{0.05}$ & 49.2 & 555.5 & 152.5 & 616.4 & 119.8 & 20.6 & 16.5 \\
\hline
\end{tabular}

${ }^{\mathrm{z}}$ All NRS units were filled with a treatment solution of $11.29 \mathrm{mg} \cdot \mathrm{L}^{-1}$ total $\mathrm{N}$ and $3.1 \mathrm{mg} \cdot \mathrm{L}^{-1}$ total $\mathrm{P}$ at the initiation and during the experiments.

yTotal solution consumption per unit was the sum of daily solution consumption by a unit over an experiment. Means were separated with Fisher's protected least significant difference (LSD) with $\alpha=0.05, \mathrm{~N}=4$ in Expt. 1 and $\mathrm{N}=2$ in Expts. 2 and 3.

${ }^{\mathrm{x}} \mathrm{N}$ and $\mathrm{P}$ received were calculated as: (total solution consumption per unit $+284 \mathrm{~L}$ initial fill solution) $\times$ treatment $\mathrm{N}$ or $\mathrm{P}$ concentrations $\left(11.29\right.$ or $3.1 \mathrm{mg} \cdot \mathrm{L}^{-1}$, respectively).

${ }^{w} \mathrm{~N}$ recovered by NRS units were calculated as: $\mathrm{N}$ provided $-\left(\left[\mathrm{NO}_{3}-\mathrm{N}\right]\right.$ concentration $+\left[\mathrm{NH}_{4}-\mathrm{N}\right]$ concentration $+\left[\mathrm{NO} \mathrm{O}_{2}-\mathrm{N}\right]$ concentration $)$ in the remaining solution at experiment termination * $284 \mathrm{~L}$; P recovered by NRS units were calculated as: $\mathrm{P}$ provided $-[\mathrm{PO}-\mathrm{P}]$ concentration in the remaining solution at experiment termination * $284 \mathrm{~L}$.

$\mathrm{v} \mathrm{N}$ recovery rate $=\mathrm{N}$ recovered $/ \mathrm{N}$ received $* 100 ; \mathrm{P}$ recovery rate $=\mathrm{P}$ recovered $/ \mathrm{P}$ received $* 100$.

"Expt. 1 was repeated and data were pooled because no significant difference was found between the two experiments.

${ }^{\text {t} M e a n s ~ w i t h i n ~ a ~ v a r i a b l e ~ c o l u m n ~ o f ~ a n ~ e x p e r i m e n t ~ n o t ~ f o l l o w e d ~ b y ~ t h e ~ s a m e ~ l e t t e r ~ a r e ~ s i g n i f i c a n t l y ~ d i f f e r e n t ~ b y ~ F i s h e r ' s ~ p r o t e c t e d ~ L S D . ~} \alpha=0.05$. $\mathrm{N}=4$ in Expt. 1 and $\mathrm{N}=2$ in Expts. 2 and 3 .

${ }^{\mathrm{s}}$ Treatment (species) effect was not significant $(P>0.05)$.

production and high harvestable tissue $\mathrm{N}$ and $\mathrm{P}$ content. Dwarf papyrus had similar shoot tissue $\mathrm{N}$ concentration as pickerelweed but lower shoot biomass and thus lower harvestable nutrient content. 'Golden Fleece' iris had higher tissue $\mathrm{N}$ concentrations than canna but much lower biomass production, and this was further compromised by the fact that the majority of the assimilated nutrients were stored in underground rhizome and thus not readily harvestable. From the perspective of NRS treatment system performance, units planted with canna had the highest $\mathrm{N}$ and $\mathrm{P}$ removal among all species, whereas other ornamental species showed less effectiveness in removing $\mathrm{N}$ and $\mathrm{P}$ from the system.

Results from this study suggest that the ornamental species canna has the potential to be used as mitigation plants in urban stormwater floating biofiltration treatment. Because canna is a perennial plant and allocates the majority of its biomass to shoots, it is possible to regularly harvest and remove biomass from the treatment system. However, more research needs to be done to evaluate factors that might affect its application such as $\mathrm{N}$ and $\mathrm{P}$ loading and hydraulic conditions, planting densities, poly culture, harvesting frequency, and growth maintenance techniques.

\section{Literature Cited}

Asaeda, T., L. Rajapaks, and T. Fujino. 2008. Applications of organ-specific growth models; modelling of resource translocation and the role of emergent aquatic plants in element cycles. Ecol. Modell. 215:170-179.

Ayaz, S.C. and L. Akca. 2001. Treatment of wastewater by natural systems. Environ. Int. 26:189-195.
Belmont, M.A. and C.D. Metcalfe. 2003. Feasibility of using ornamental plants (Zantedeschia aethiopica) in subsurface flow treatment wetlands to remove nitrogen, chemical oxygen demand and nonylphenol ethoxylate surfactants - A laboratory-scale study. Ecol. Eng. 21:233-247.

Bolund, P. and S. Hunhammer. 1999. Ecosystem services in urban areas. Ecol. Econ. 29:293-301.

Chen, Y., R.L. Parish, D.J. Merhaut, and R.P. Bracy. 2008. Description of an improved hydroponic research system for screening plants for nutrient abatement in constructed wetlands. Appl. Eng. In Agr. 24:697-702.

Crab, R., Y. Avnimelech, T. Defoirdt, P. Bossier, and W. Verstraete. 2007. Nitrogen removal techniques in aquaculture for a sustainable production. Aquaculture 270:1-14.

Davis, A.P. 2005. Green engineering principles promotes low impact development. Environ. Sci. Technol. 39:338A-344A.

Davis, A.P. 2007. Field performance of bioretention: Water quality. Environ. Eng. Sci. 24: 1048-1064.

DeBusk, T.A., J.E. Peterson, and K.R. Jensen. 1995. Phosphorus removal from agricultural runoff: An assessment of macrophyte and periphyton-based treatment systems, p. 619-627. In: Campbell, K. (ed.). Versatility of wetlands in the agricultural landscape. American Society of Agricultural Engineers, St. Joseph, MI.

Dougherty, M., R.L. Dymond, T.J. Grizzard, Jr., A.N. Godrej, C.E. Zipper, and J. Randolph. 2006. Quantifying long-term NPS pollutant flux in an urbanizing watershed. J. Environ. Eng. 132:547-554.

EPA. 1983. Methods for the chemical analysis of water and wastes (MCAWW) (EPA/600/4-79/ 020, revised 1983). NTIS PB-123677.

Granéli, W., E.E.B. Weisner, and M.D. Systma. 1992. Rhizome dynamics and resource storage in Phragmites australis. Wetlands Ecol. Manage. 1:239-247.
Hadad, H.R. and M.A. Maine. 2007. Phosphorous amount in floating and rooted macrophytes growing in wetlands from the Middle Paraná River floodplain (Argentina). Ecol. Eng. 31: 251-258.

Hadad, H.R., M.A. Maine, and C.A. Bonetto. 2006. Macrophyte growth in a pilot-scale constructed wetland for industrial wastewater treatment. Chemosphere 63:1744-1753.

Hatt, B.E., T.D. Fletcher, and A. Deletic. 2009. Hydrologic and pollutant removal performance of stormwater biofiltration systems at the field scale. J. Hydrol. 365:310-321.

Henderson, C., M. Greenway, and I. Phillips. 2007. Removal of dissolved nitrogen, phosphorus and carbon from stormwater by biofiltration mesocosms. Water Sci. Technol. 55:183-191.

Jayaweera, M.W. and J.C. Kasturiarachchi. 2004. Removal of nitrogen and phosphorus from industrial wastewaters by phytoremediation using water hyacinth Eichhornia crassipes (Mart.). Solms. Water Sci. and Technol. 50: 217-225.

Marschner, H. 1995. Mineral nutrients of higher plants. 2nd Ed. Academic Press, San Diego, CA

Miyazaki, A., T. Takeuchi, H. Nakamura, Y. Yamamoto, and F. Kubota. 2004. Characteristics of nutrient absorption and water purification in some plant species grown by floating culture system. Soil Sci. Plant Nutr. 50:357-363.

Moustafa, M.Z. 1999. Nutrient detention dynamics of the Everglades Nutrient Removal project. Wetlands 19:689-704.

Odum, W.E. and M.A. Heywood. 1978. Decomposition of intertidal freshwater marsh plants. Freshwater Wetlands. Ecological Processes and Management Potential. Proc. of the Symposium Freshwater Marshes: Present Status, Future Needs, Rutgers University, New Brunswick. p. 89-97.

Ou, W., Y. Lin, S. Jing, and H. Lin. 2006. Performance of a constructed wetland-pond 
system for treatment and reuse of wastewater from campus buildings. Water Environ. Res. 78:2369-2376.

Polomski, R.F., D.G. Bielenberg, T. Whitwell, M.D. Taylor, W.C. Bridges, and S.T. Klaine. 2007. Nutrient recovery by seven aquatic garden plants in a laboratory-scale subsurface-constructed wetland. HortScience 42:1674-1680.

Read, J., T. Wevill, T. Fletcher, and A. Deletic. 2008. Variation among plant species in pollutant removal from stormwater in biofiltration systems. Water Res. (Oxford) 42:893-902.

Richards, J.H. and C.T. Ivey. 2004. Morphological plasticity of Sagittaria lancifolia in response to phosphorus. Aquat. Bot. 80:53-67.

Schaefer, M. 1997. Stormwater management: An environmental challenge beyond the 20th century. Water Eng. Mgt. 144:28-29.

Schueler, T.R. 1992. Design of stormwater wetland systems: Guidelines for creating diverse and effective stormwater wetlands in the midAtlantic region. Anacostia Restoration Team, Dept. of Environmental Programs, Metropolitan Washington Council of Governments, Washington, DC.

Serrano, L. and M.E. DeLorenzo. 2008. Water quality and restoration in a coastal subdivision stormwater pond. J. Environ. Manage. 88:4352.

Srivastava, J., A. Gupta, and H. Chandra. 2008. Managing water quality with aquatic macrophytes. Rev. Environ. Sci. Biotechnol. 7:255266.

Steuer, J., W. Selbig, N. Hornewer, and J. Prey. 1997. Sources of contamination in an urban basin in Marguette, Michigan and an analysis of concentrations, loads, and data quality. US Dept. of the Interior, US Geological Survey, Water Resources Investigations Rpt. $97-$ 4242 .

Stewart, F.M., T. Mulholland, A.B. Cunningham, B.G. Kania, and M.T. Osterlund. 2008. Floating islands as an alternative to constructed wetlands for treatment of excess nutrients from agricultural and municipal wastes - Results of laboratory-scale tests. Land Contamination \& Reclamation 16:25-33.

Tuncsiper, B., S.C. Ayaz, L. Akca, and A. Samsunlu. 2005. Nitrogen management in reservoir catchments through constructed wetland systems. Water Sci. Technol. 51:175-181.

US Environmental Protection Agency. 1986. Quality criteria for water. EPA Document No. 440/ 5-86-001. US EPA Office of Water Regulation and Standards. US Govt. Print. Office (PB87226759), Washington, DC.

Walsh, C.J. 2000. Urban impact on the ecology of receiving waters: A framework for assessment, conservation, and restoration. Hydrobiologia 431:107-114.

Wolverton, B.C. 1990. Aquatic plant microbial filters for treating septic tank effluent, p. 173178. In: Hammer, D.A. (ed.). Constructed wetlands for wastewater treatment. Lewis Publishers, New York, NY.

Zhang, Z.H., Z. Rengel, and K. Meney. 2007. Nutrient removal from simulated wastewater using Canna indica and Schoenoplectus validus in mono- and mixed-culture in wetland microcosms. Water Air Soil Pollut. 183:95-105.

Zhang, Z.H., Z. Rengel, and K. Meney. 2008. Interactive effects of nitrogen and phosphorus loadings on nutrient removal from simulated wastewater using Schoenoplectus validus in wetland microcosms. Chemosphere 72:18231828.

Zurita, F., J. de Anda, and M.A. Belmont. 2006. Performance of laboratory-scale wetlands planted with tropical ornamental plants to treat domestic wastewater. J. of Canada Water Quality Res. 41:410-417. 